\title{
Analysis of fatty acid composition content in the plant components of antidiabetic herbal mixture by GC-MS
}

\author{
Alona Savych ${ }^{1}$, Roksolana Basaraba ${ }^{2}$, Nataliia Muzyka², Pavlina Ilashchuk ${ }^{2}$ \\ 1 I. Horbachevsky Ternopil National Medical University, Ternopil, Ukraine \\ 2 Bukovinian State Medical University, Chernivtsi, Ukraine \\ Corresponding author: Alona Savych (alonasavych@gmail.com)
}

Received 30 March 2021 • Accepted 8 May 2021 • Published 20 May 2021

Citation: Savych A, Basaraba R, Muzyka N, Ilashchuk P (2021) Analysis of fatty acid composition content in the plant components of antidiabetic herbal mixture by GC-MS. Pharmacia 68(2): 433-439. https://doi.org/10.3897/pharmacia.68.e66693

\begin{abstract}
Medical plants and their combinations due to the wide range of biologically active substances can influence on various links of the pathogenetic mechanism of development of diabetes mellitus and its complications. One of such combinations is an anidiabetic herbal mixture (Urtica dioica L. leaf, Rosa majalis L. fruits, Vaccinium myrtillus L. leaf, Mentha piperita L. herb and Taraxacum officinale L. roots) with established hypoglycemic, hypolipidemic, antioxidant, hepatoprotective, pancreatoprotective activity in previous pharmacological study in vivo. Thus, the aim of this study was to identify and establish the fatty acid content in the plant components of antidiabetic herbal mixture. Fatty acids were separated by validated method of of gas chromatography-mass spectrometry after conversion into methyl esters. The result showed that Urtica dioica L. leaf and Vaccinium myrtillus L. leaf contain 12 fatty acids (8 saturated, 2 monounsaturated and 2 polyunsaturated), Rosa majalis L. fruits and Taraxacum officinale L. roots - 13 fatty acids ( 9 saturated, 2 monounsaturated and 2 polyunsaturated) and Mentha piperita L. herb - 14 fatty acids (10 saturated, 2 monounsaturated and 2 polyunsaturated). The predominant long-chain carboxylic acids in all plant raw materials were unsaturated fatty acids, their content was $55.3 \%$ in Urtica dioica L. leaf, 64.7\% in Rosa majalis L. fruits, $60.5 \%$ in Vaccinium myrtillus L. leaf, $64.3 \%$ in Mentha piperita L. herb and $51.7 \%$ in Taraxacum officinale L. roots. This indicates the feasibility of including each component in the antidiabetic herbal mixture in order to form anticholesterolemic, anti-inflammatory, immunomodulatory and neuroprotective activity, due to the high content of omega-3, omega- 6 and omega- 9 fatty acids.
\end{abstract}

\section{Keywords}

diabetes mellitus, herbal mixture, GC-MS, fatty acids, Urtica dioica L. leaf, Rosa majalis L. fruits, Vaccinium myrtillus L. leaf, Mentha piperita L. herb and Taraxacum officinale L. roots

\section{Introduction}

Diabetes mellitus is one of WHO's priorities matters, which requires immediate solutions, as the epidemiological situation is alarming - the number of patients is growing each year, leading to increased disability and mortality due to the development of diabetic angiopathies (Harding et al. 2019;
American Diabetes Association 2021). According to the official information of International Diabetes Federation (2019) the number of diabetics will increase to 700 million by 2045 . Therefore, the implementation of pharmacotherapy optimization, the search and study of new drugs for the prevention and treatment of this disease and its dangerous complications is a topical issue of pharmacy and medicine. 
Modern pharmacotherapy increasingly takes into account the centuries-old experience of folk medicine with the use of phytopreparations as monotherapy and in combination with synthetic drugs. This is quite justified, because phytotherapy has a number of advantages over traditional therapy with synthetic drugs, namely, it is low-toxic, has a mild pharmacological effect and can be used for a long period of time without significant side effects and combines well with synthetic drugs (Gothai et al. 2016; Governa et al. 2018). In addition, herbal medicines, as a rule, have a wide range of pharmacological properties, which is realized through different groups of phytochemicals (Oh and Jun 2014; Kooti et al. 2016; Marchyshyn et al. 2020). Combinations of different medicinal plants deserve special attention as such herbal mixtures will have more biologically active substances that will affect all parts of the pathogenetic mechanism of diabetes mellitus and its complications (Savych et al. 2020a, b, c, d, e, f, 2021a, b, c, d, e).

One of such combinations is an anidiabetic herbal mixture (Urtica dioica L. leaf, Rosa majalis L. fruits, Vaccinium myrtillus L. leaf, Mentha piperita L. herb and Taraxacum officinale L. roots) with established hypoglycemic, hypolipidemic, antioxidant, hepatoprotective, pancreatoprotective activity in pharmacological study in vivo (Savych et al. 2020b, c, d, e, f, 2021e) and the defined phytochemical composition that determines such pharmacodynamics (Savych et al. 2020a, 2021a, b, c, d).

Biologically active substances of plant origin have a wide range of pharmacological action and a variety of mechanisms of influencing on the development of diabetes and its complication (Oh and Jun 2014; Kooti et al. 2016; Skyler et al. 2017). One of the most influential phytochemicals are fatty acids, because they have the ability to regulate the lipid metabolism, a disorder of which occurs in diabetes and leads to the development of cardiovascular diseases and microcirculatory complications - diabetic nephropathy, neuropathy and retinopathy, the formation of diabetic foot. Carboxylic acids with a long aliphatic chain have the ability to prevent the oxidation of cell membrane lipids, contribute to the reduction of blood cholesterol, normalize lipid and protein metabolism, increase the liver's detoxification function, stimulate immune-protective function, increase the elasticity and reduce the permeability of the walls of blood vessels, improve microcirculation (Sears and Perry 2015; Rogero and Calder 2018). Especially important for the human body is linoleic acid, which is part of the omega- 6 fatty acids, and linolenic acid - of omega-3 fatty acids, which normalize the function of subcellular and cellular membranes (Brown et al. 2019).

\section{Aim of the research}

The aim of this study was to identify and to establish the fatty acid content in Urtica dioica L. leaf, Rosa majalis L. fruits, Vaccinium myrtillus L. leaf, Mentha piperita L. herb and Taraxacum officinale L. roots as the plant components of antidiabetic herbal mixture.

\section{Materials and methods (experimental part)}

It was used the herbal raw materials of Urtica dioica L. leaf, Rosa majalis L. fruits, Vaccinium myrtillus L. leaf, Mentha piperita L. herb and Taraxacum officinale L. roots harvested from June to October 2020 in Ternopil region and Charpathians (Vaccinium myrtillus L. leaf) (Ukraine) during the study. The raw materials were then dried, crushed and stored according to the general GACP requirements (WHO 2003). Plant was identified by Department of Pharmacognosy with Medical Botany, Ivan Horbachevsky Ternopil National Medical University, Ternopil, Ukraine. Sample of herbal raw materials has been deposited in Departmental Herbarium for future record.

All herbal raw materials used in the study were the components of antidiabetic herbal mixture with established hypoglycemic, hypolipidemic, antioxidant, hepatoprotective, pancreatoprotective activity in pharmacological study in vivo (Savych et al. 2020b, c, d, e, f, 2021e) and the defined phytochemical composition that determines such pharmacodynamics (Savych et al. 2020a, 2021a, b, c, d).

\section{Chemicals and standards}

All applied reagents were of analytical grade ( $\geq 99 \% \mathrm{pu}-$ rity). Standard carboxylic acids were purchased from Sigma-Aldrich Chemical Co. (St. Louis, MO, USA). Water used in the studies was produced by MilliQ Gradient water deionizaton system (Millipore, Bedford, MA, USA). Methanol, toluene, sulfuric acid and heptane were purchased from Sigma-Aldrich Chemical Co. (St. Louis, MO, USA).

\section{Chromatographic condition}

Fatty acid composition of herbal raw materials was studied by gas chromatography-mass spectrometry (GCMS). Chromatographic separation was performed on a gas chromato-mass spectrometric system model $6890 \mathrm{~N} / 5973$ inert (Agilent Technologies, USA) using a capillary column HP-5 ms $(30 \mathrm{~m} \times 0.25 \mathrm{~mm} \times 0.25 \mathrm{mkm}$, Agilent Technologies, USA). Evaporator temperature was $250{ }^{\circ} \mathrm{C}$, the interface temperature $-280{ }^{\circ} \mathrm{C}$. Separation was performed in the mode of temperature programming from 60 to $320^{\circ} \mathrm{C}$ at a speed of $7 \mathrm{deg} / \mathrm{min}$. Samples of $1 \mu \mathrm{L}$ were administered in a 1:50 flow divider mode. Detection was held in the SCAN mode in the range of $(38-400 \mathrm{~m} / \mathrm{z})$. Carrier gas flow rate through a column was $1.0 \mathrm{~mL} / \mathrm{min}$ (Ecker et al. 2012).

\section{Sample preparation with pre-column derivatization}

Samples of herbal raw materials were grinded into a powder by laboratory mill and about $0.5 \mathrm{~g}$ (accurately mass) were selected and placed into a glass vial. Then $3.3 \mathrm{~mL}$ of 


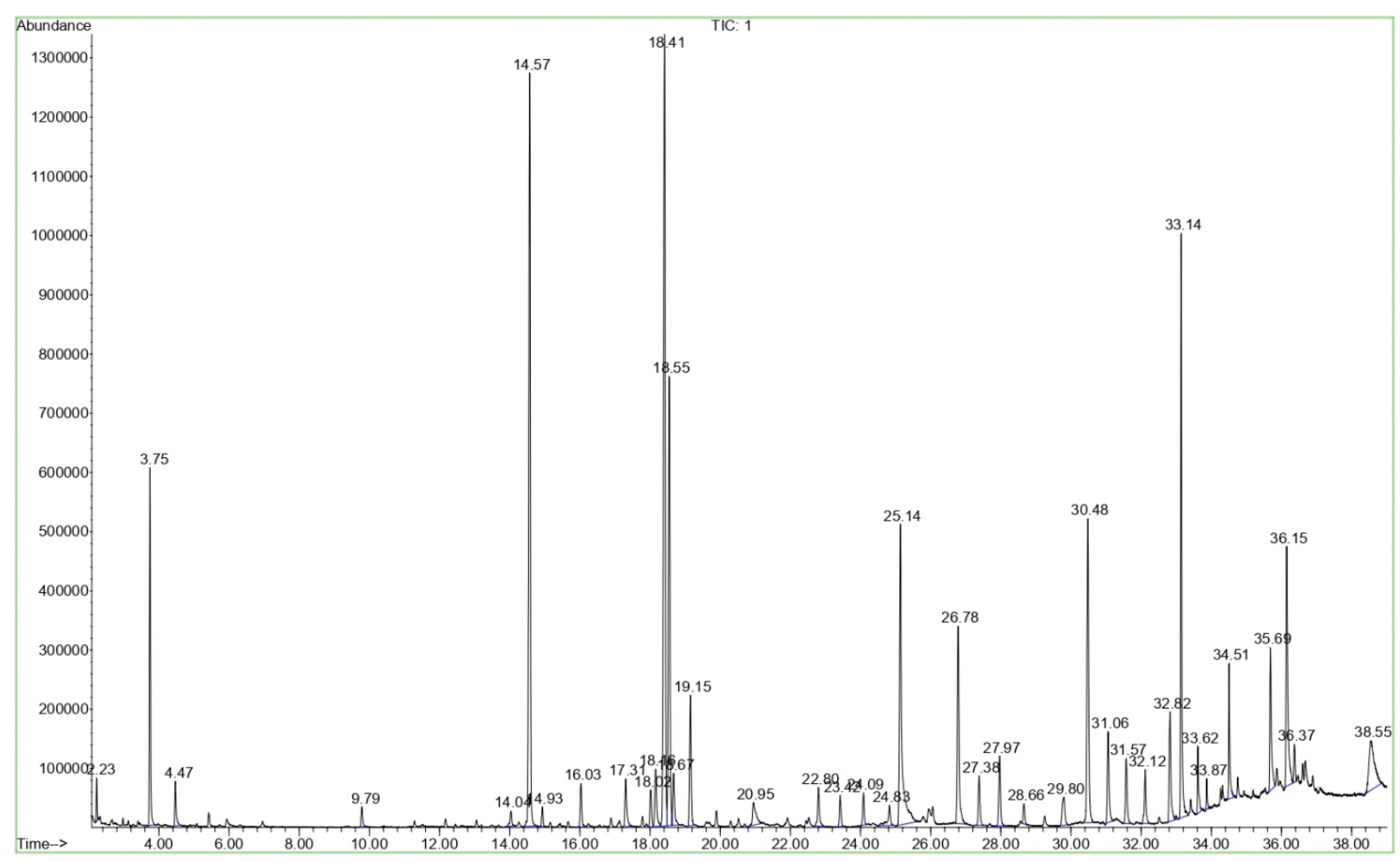

Figure 1. GC-MS chromatogram of fatty acids in Urtica dioica L. leaf.

reacting mixture (methanol: toluene: sulfuric acid (44:20:2 $\mathrm{v} / \mathrm{v}$ )) with $1.7 \mathrm{~mL}$ of internal standard solution (undecanoic acid in heptane solution) was added. The obtained samples were standed at $80{ }^{\circ} \mathrm{C}$ for 2 hours, refrigerated and centrifuged for 10 minutes at $5000 \mathrm{rpm}$. It was taken $0.5 \mathrm{~mL}$ of the upper heptane phase, which containing methyl esters of fatty acids (Ecker et al. 2012).

\section{Identification and calculation}

Identification of methyl esters of fatty acids was performed by comparing of retention time $\left(t_{R}\right)$ of the mixture of standard and using the NIST 05 and WILEY 2007 mass spectrum library in combination with programs for identification of AMDIS.

Quantitative content $(X, \mathrm{mg} / \mathrm{kg})$ was determined by the method of internal standards according to the formula:

$$
X=\frac{S x \times m 1 \times 1000}{S 1 \times m}
$$

where $S 1$-peak area of the studied substance;

$m 1$ - mass of the internal standard injected into the sample, mg;

$S x$ - peak area of the standard;

$m$ - sample of raw materials, $\mathrm{mg}$.

\section{Method validation}

The method was validated for linearity, limit of detection (LOD), limit of quantitation (LOQ) and precision. Linearity was performed by injecting a series of standard solutions of fatty acids methyl esters (0.1-10.0 mg/100 g) with a threefold derivatization procedure and a single injection for each reference standard. The mean value and standard deviation, as well as regression analysis were calculated using Microsoft Excel software package 2016 (USA). The values for LOD and LOQ were calculated based on the data obtained during linearity testing in the low concentration range of the working in the test solution, using the following formulas: $\mathrm{LOD}=3.3{ }^{*} \mathrm{~s} /$ Slope; LOQ $=10^{*} \mathrm{~s} /$ Slope. Linearity testing was repeated with the same samples after a complete restart of the system with removement and re-installation of the column. Repeatability precision was determined by five-fold injection of the same sample in a row. For the resulting relative peak area of the quantifier ions the relative standard deviation (RSD) was calculated. To determine intra-day precision, five standard preparations of each reference standard of fatty acids methyl esters with the same concentration were single injected and the resulting relative peak areas were used to calculate the RSD. Inter-day precision for the day of sample preparation and the two following days was specified by injecting five standard sample of each reference standard preparations once each on all three days. The RSD of the samples on that day together with the previous samples were calculated as above (Ecker et al. 2012).

\section{Results and discussion}

According to the results of the GC-MS analysis, it was identified 12 fatty acids, in particular 8 saturated, 2 monounsaturated and 2 polyunsaturated in Urtica dioica L. leaf (Fig. 1) and in Vaccinium myrtillus L. leaf (Fig. 3). As can be seen on the chromatograms in Rosa majalis L. 


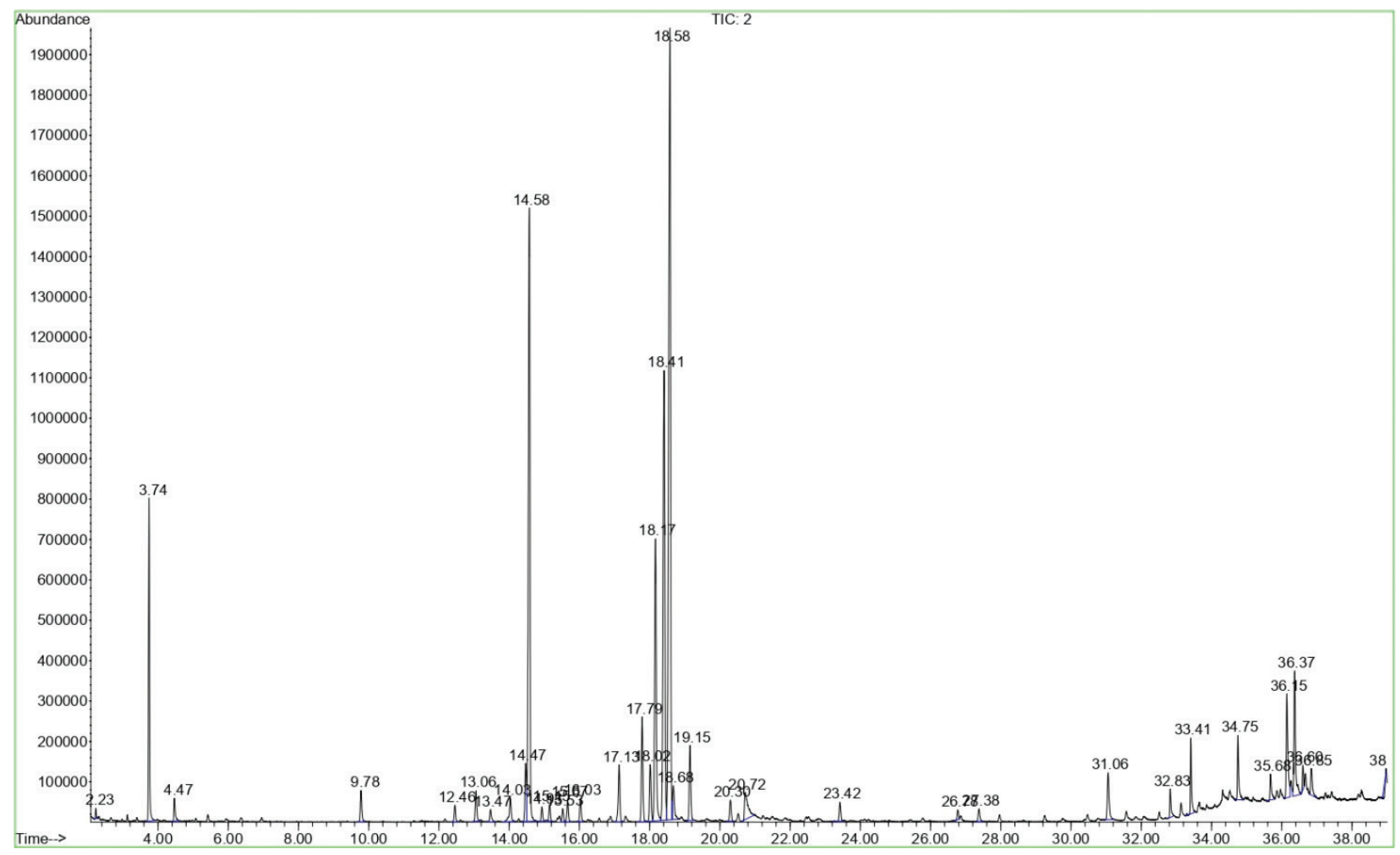

Figure 2. GC-MS chromatogram of fatty acids in Rosa majalis L. fruits.

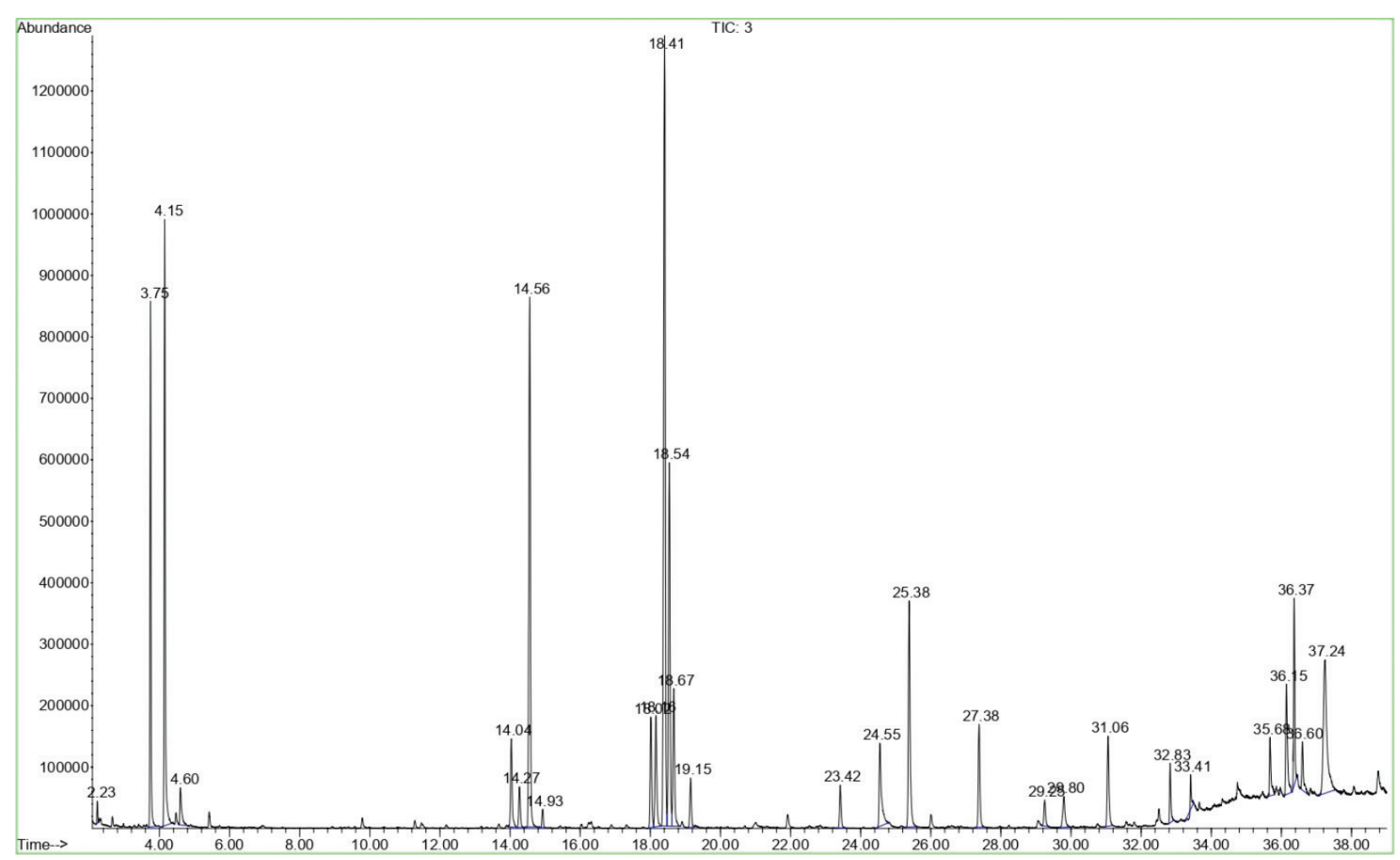

Figure 3. GC-MS chromatogram of fatty acids in Vaccinium myrtillus L. leaf.

fruits (Fig. 2) and in Taraxacum officinale L. roots (Fig. 5) 13 fatty acids ( 9 saturated, 2 monounsaturated and 2 polyunsaturated) were identified. As for Mentha piperita L. herb, it was found 14 fatty acids, namely 10 saturated, 2 monounsaturated and 2 polyunsaturated (Fig. 4).
The results of the quantitative study showed that the predominant saturated fatty acid component in all test samples was palmitic acid. It was mostly found in Rosa majalis L. fruits $(4.73 \pm 0.05 \mathrm{mg} / \mathrm{g})$ and in Urtica dioica L. leaf $(4.48 \pm 0.07 \mathrm{mg} / \mathrm{g})$. In all samples of plant raw materials 


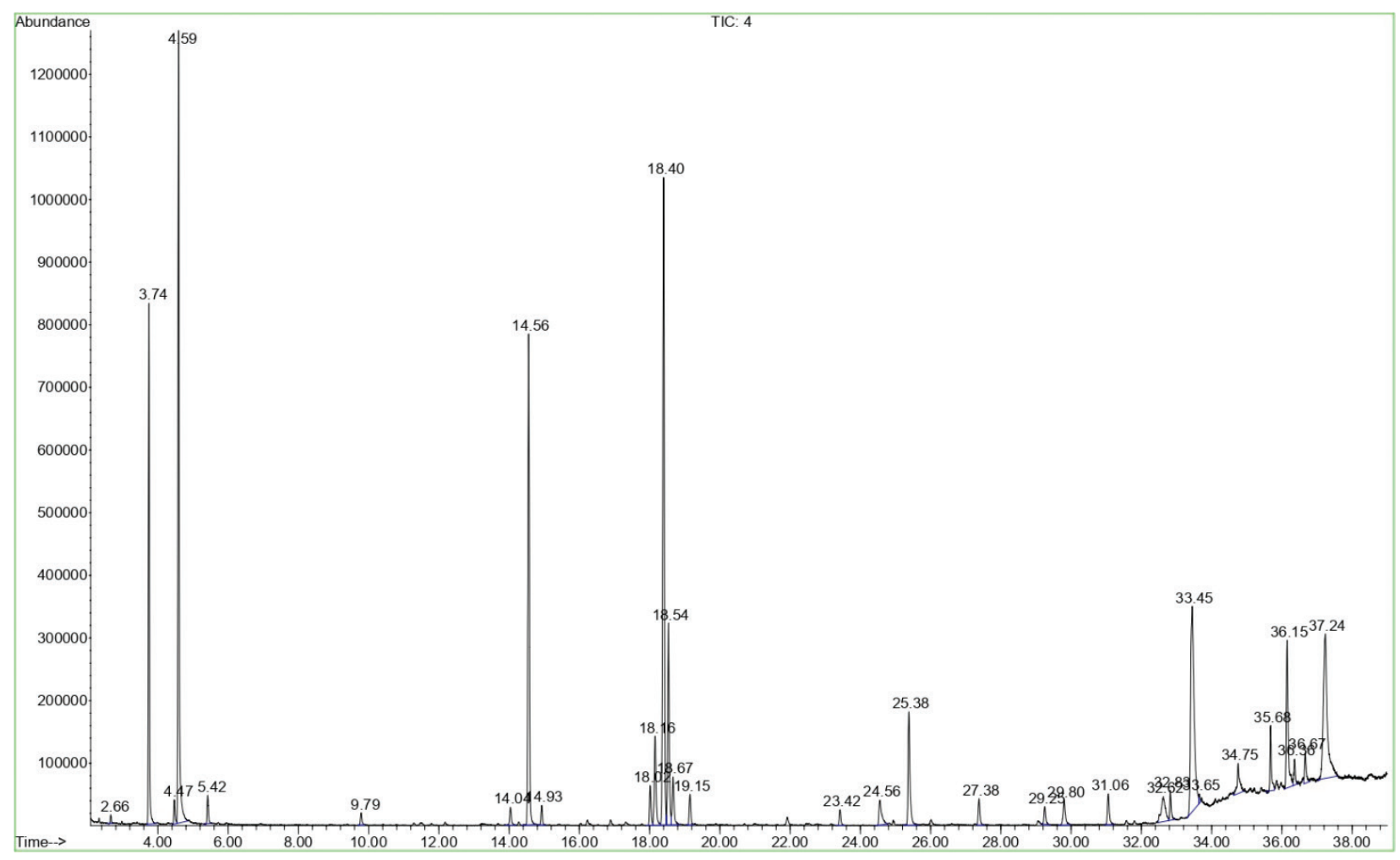

Figure 4. GC-MS chromatogram of fatty acids in Mentha piperita L. herb.

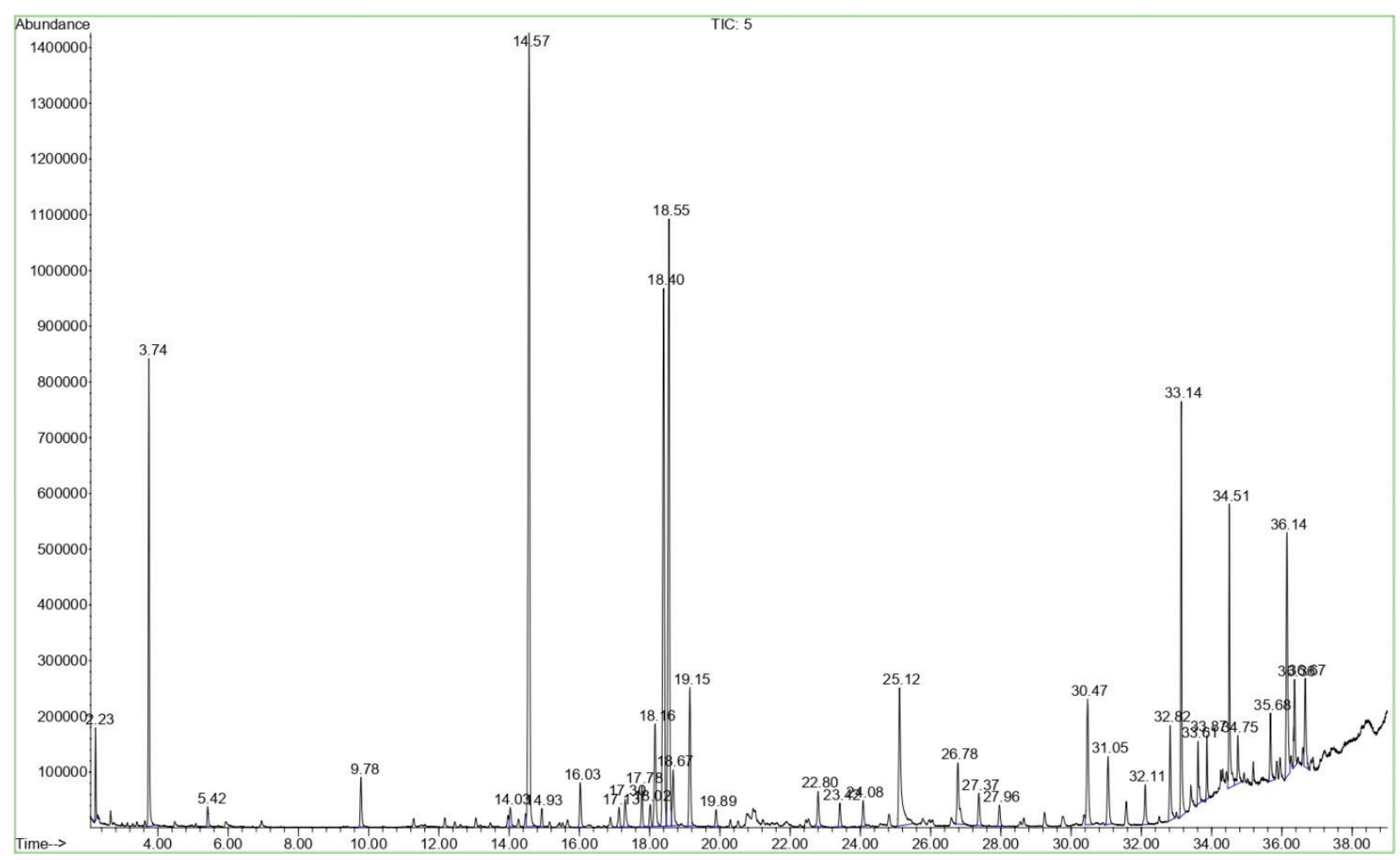

Figure 5. GC-MS chromatogram of fatty acids in Taraxacum officinale L. roots.

were found two monounsaturated fatty acids - predominant oleic and palmitoleic. Oleic acid, which is part of omega-9, was found in the largest amount in Vaccinium myrtillus L. leaf $(0.81 \pm 0.02 \mathrm{mg} / \mathrm{g})$, in Rosa majalis L. fruits $(0.69 \pm 0.02 \mathrm{mg} / \mathrm{g})$ and in Taraxacum officinale L. roots
$(0.61 \pm 0.02 \mathrm{mg} / \mathrm{g})$. As for polyunsaturated fatty acids, two of them - linoleic and linolenic, were also identified in all five plant components of the antidiabetic herbal mixture. Linoleic acid, which is part of omega-6, was present in fairly large quantities in the studied objects, but in the 
Table 1. The results of the GC-MS analysis of fatty acids content in the plant components of antidiabetic herbal mixture.

\begin{tabular}{|c|c|c|c|c|c|c|c|c|}
\hline \multirow[t]{2}{*}{ No. } & \multirow[t]{2}{*}{$t_{R}$} & \multirow[t]{2}{*}{ Common name of fatty acid } & \multirow{2}{*}{$\begin{array}{c}\text { Chemical } \\
\text { nomen-clature }\end{array}$} & \multicolumn{5}{|c|}{ Quantitative content of fatty acids methyl esters, $\mathrm{mg} / \mathrm{g}$} \\
\hline & & & & $\begin{array}{l}\text { Urtica dioica } \\
\text { L. leaf }\end{array}$ & $\begin{array}{l}\text { Rosa majalis } \\
\text { L. fruits }\end{array}$ & $\begin{array}{l}\text { Vaccinium myrtillus } \\
\text { L. leaf }\end{array}$ & $\begin{array}{c}\text { Mentha piperita } \mathrm{L} . \\
\text { herb }\end{array}$ & $\begin{array}{l}\text { Taraxacum officinale } \\
\text { L. roots }\end{array}$ \\
\hline \multicolumn{9}{|c|}{ Saturated acids } \\
\hline 1. & 2.66 & Capric (decanoic) & C 10:0 & - & - & - & $0.06 \pm 0.01$ & - \\
\hline 2. & 3.74 & Undecylic (undecanoic) & C 11:0 & \multicolumn{5}{|c|}{ Internal standart } \\
\hline 3. & 5.42 & Lauric (dodecanoic) & C 12:0 & - & - & - & $0.21 \pm 0.01$ & $0.08 \pm 0.01$ \\
\hline 4. & 9.78 & Myristic (tetradecanoic) & C 14:0 & $0.11 \pm 0.01$ & $0.21 \pm 0.01$ & - & $0.08 \pm 0.01$ & $0.31 \pm 0.02$ \\
\hline 5. & 14.04 & Pentadecylic (pentadecanoic) & C $15: 0$ & $0.07 \pm 0.01$ & $0.07 \pm 0.01$ & $0.12 \pm 0.01$ & $0.08 \pm 0.01$ & $0.16 \pm 0.01$ \\
\hline 6. & 14.57 & Palmitic (hexadecanoic) & C 16:0 & $4.48 \pm 0.07$ & $4.73 \pm 0.05$ & $2.34 \pm 0.04$ & $2.71 \pm 0.03$ & $3.84 \pm 0.07$ \\
\hline 7. & 16.03 & Margaric (heptadecanoic) & C 17:0 & $0.26 \pm 0.01$ & $0.16 \pm 0.02$ & - & - & $0.29 \pm 0.02$ \\
\hline 8. & 19.15 & Stearic (octadecanoic) & C 18:0 & $0.76 \pm 0.02$ & $0.52 \pm 0.02$ & $0.28 \pm 0.01$ & $0.25 \pm 0.01$ & $0.85 \pm 0.03$ \\
\hline 9. & 23.42 & Arachidic (eicosanoic) & C 20:0 & $0.18 \pm 0.01$ & $0.13 \pm 0.01$ & $0.27 \pm 0.01$ & $0.12 \pm 0.01$ & $0.31 \pm 0.01$ \\
\hline 10. & 27.38 & Behenic (docosanoic) & C 22:0 & $0.31 \pm 0.01$ & $0.10 \pm 0.01$ & $0.54 \pm 0.03$ & $0.18 \pm 0.02$ & $0.37 \pm 0.02$ \\
\hline 11. & 29.03 & Tricosylic (tricosanoic) & C 23:0 & - & - & $0.22 \pm 0.01$ & - & - \\
\hline 12. & 31.06 & Lignoceric (tetracosanoic) & C 24:0 & $0.57 \pm 0.01$ & $0.39 \pm 0.02$ & $0.51 \pm 0.04$ & $0.28 \pm 0.02$ & $0.65 \pm 0.03$ \\
\hline 13. & 32.38 & Pentacosylic (pentacosanoic) & C 25:0 & - & - & - & $0.19 \pm 0.01$ & - \\
\hline 14. & 33.41 & Cerotic (hexacosanoic) & C 26:0 & - & $0.08 \pm 0.01$ & $0.11 \pm 0.01$ & - & - \\
\hline \multicolumn{9}{|c|}{ Monounsaturated acids } \\
\hline 15. & 18.67 & Oleic (octadecenoic, $\omega-9$ ) & C $18: 1$ & $0.36 \pm 0.01$ & $0.69 \pm 0.02$ & $0.81 \pm 0.02$ & $0.48 \pm 0.01$ & $0.61 \pm 0.02$ \\
\hline 16. & 14.04 & almitoleic acid (hexadecenoic, $\omega-7$ ) & C $16: 1$ & $0.10 \pm 0.01$ & $0.39 \pm 0.03$ & $0.57 \pm 0.02$ & $0.29 \pm 0.01$ & $0.29 \pm 0.01$ \\
\hline \multicolumn{9}{|c|}{ Polyunsaturated acids } \\
\hline 17. & 18.41 & Linoleic (octadecadienic, $\omega-6$ ) & C $18: 2$ & $5.22 \pm 0.06$ & $3.67 \pm 0.06$ & $3.39 \pm 0.05$ & $3.73 \pm 0.05$ & $2.96 \pm 0.04$ \\
\hline 18. & 18.56 & Linolenic (octadecatrienic, $\omega-3$ ) & C $18: 3$ & $2.67 \pm 0.04$ & $7.07 \pm 0.08$ & $1.91 \pm 0.04$ & $2.98 \pm 0.02$ & $3.49 \pm 0.04$ \\
\hline \multicolumn{4}{|c|}{ The amount of saturated fatty acids } & 6.74 & 6.39 & 4.39 & 4.16 & 6.86 \\
\hline \multicolumn{4}{|c|}{ The amount of unsaturated fatty acids } & 8.35 & 11.72 & 6.68 & 7.48 & 7.35 \\
\hline \multicolumn{4}{|c|}{ Total } & 15.09 & 18.11 & 11.07 & 11.64 & 14.21 \\
\hline
\end{tabular}

Note: Values are expressed as mean $\pm \operatorname{SD}(n=5)$.

largest - in Urtica dioica L. leaf $(5.22 \pm 0.06 \mathrm{mg} / \mathrm{g})$. As for another polyunsaturated acid, namely linolenic, which belongs to the class of omega-3, its highest content was found in Rosa majalis L. fruits $(7.07 \pm 0.08 \mathrm{mg} / \mathrm{g})$ (Table 1).

According to the chromatographic study, it was determined that the total content of fatty acids in Urtica dioica L. leaf was $15.09 \mathrm{mg} / \mathrm{g}$, in Rosa majalis L. fruits was $18.11 \mathrm{mg} / \mathrm{g}$, in Vaccinium myrtillus L. leaf was $11.07 \mathrm{mg} / \mathrm{g}$, in Mentha piperita L. herb was $11.64 \mathrm{mg} / \mathrm{g}$ and in Taraxacum officinale L. roots was $14.21 \mathrm{mg} / \mathrm{g}$. The predominant fatty acids in all plant raw materials were unsaturated fatty acids and their content was $55.3 \%$ in Urtica dioica L. leaf, $64.7 \%$ in Rosa majalis L. fruits, $60.5 \%$ in Vaccinium myrtillus L. leaf, $64.3 \%$ in Mentha piperita L. herb and 51.7\% in Taraxacum officinale L. roots (Table 1).

The results show that all plant components, such as Urtica dioica L. leaf, Rosa majalis L. fruits, Vaccinium myrtillus L. leaf, Mentha piperita L. herb and Taraxacum officinale L. roots, of the antidiabetic herbal mixture have a high content of unsaturated fatty acids, which provide a number of pharmacological properties of this phytomixture. Unsaturated fatty acids belonging to the class of omega-3, omega-6 and omega-9 play have an important role in the human body, namely, provide cell membrane function, exhibit anticholesterolemic activity, converting cholesterol into cholic acids and removing them from the body, take involved in fat metabolism (Sears and Perry 2015; Brown et al. 2019). In addition, they have anti-inflammatory effects, as they are involved in the synthesis of prostaglandins, as well as show immunomodulatory activity, improve blood circulation and nervous system function. All these properties of fatty acids are important for the treatment of patients with diabetes and prevention of complications in the form of diabetic micro- and macroangiopathies (Li et al. 2018; Rogero and Calder 2018).

This phytochemical study is a confirmation of the fatty acid composition of the antidiabetic herbal mixture (Urtica dioica L. leaf, Rosa majalis L. fruits, Vaccinium myrtillus L. leaf, Mentha piperita L. herb and Taraxacum officinale L. roots) as a whole, which was studied in previous research (Savych et al. 2020a-f?) and shows due to which plant components it is formed. This indicates the feasibility of including each component in the antidiabetic mixture in order to form anticholesterolemic, anti-inflammatory, immunomodulatory and neuroprotective activity, which is necessary for the complex therapy of diabetes.

The analytical procedure has been validated to confirm its reliability. All the peaks of reference standards showed good linearity $(\mathrm{R} 2>0.995)$ in a wide concentration range $(0.1-10.0 \mathrm{mg} / 100 \mathrm{~g})$. The results showed that the LODs and the LOQs of methyl esters of fatty acids were in the range of $0.01-0.07 \mathrm{mg} / 100 \mathrm{~g}$ and $0.03-0.22 \mathrm{mg} / 100 \mathrm{~g}$, respectively, indicating that the sensitivity of the method was satisfactory. The repeatability of the subsequent derivatization and GC-measurement of five standard samples of each reference standard with the same concentration resulted in precision values for the derivatization procedure. For intra- and inter-day precision, the RSD was in a range of $1.57 \%$ to $6.26 \%$, which is acceptable.

\section{Conclusion}

We identified and established the quantity content of fatty acid composition of Urtica dioica L. leaf, Rosa majalis L. fruits, Vaccinium myrtillus L. leaf, Mentha piperita L. herb 
and Taraxacum officinale L. roots, which are plant components of antidiabetic herbal mixture with hypoglycemic, hypolipidemic, antioxidant, hepatoprotective, pancreatoprotective activity and defined phytochemical composition by GC-MS method. The total content of fatty acids in Urtica dioica L. leaf was $15.09 \mathrm{mg} / \mathrm{g}$, in Rosa majalis L. fruits was $18.11 \mathrm{mg} / \mathrm{g}$, in Vaccinium myrtillus L. leaf was $11.07 \mathrm{mg} / \mathrm{g}$, in Mentha piperita L. herb was $11.64 \mathrm{mg} / \mathrm{g}$ and in Taraxacum officinale L. roots was $14.21 \mathrm{mg} / \mathrm{g}$. The predominant long-

\section{References}

American Diabetes Association (2021) Introduction: Standards of Medical Care in Diabetes-2021. Diabetes Care 44(1): 1-2. https://doi. org/10.2337/dc21-Sint

Brown TJ, Brainard J, Song F, Wang X, Abdelhamid A, Hooper L (2019) Omega-3, omega-6, and total dietary polyunsaturated fat for prevention and treatment of type 2 diabetes mellitus: Systematic review and meta-analysis of randomised controlled trials. BMJ 366: el4697. https://doi.org/10.1136/bmj.14697

Ecker J, Scherer M, Schmitz G, Liebisch G (2012) A rapid GC-MS method for quantification of positional and geometric isomers of fatty acid methyl esters. Journal of Chromatography B: Analytical Technologies in the Biomedical and Life Sciences 897: 98-104. https://doi. org/10.1016/j.jchromb.2012.04.015

Gothai S, Ganesan P, Park S, Fakurazi, S, Choi D, Arulselvan P (2016) Natural phyto-bioactive compounds for the treatment of type $2 \mathrm{di}$ abetes: inflammation as a target. Nutrients 8(8): e461. https://doi. org/10.3390/nu8080461

Governa P, Baini G, Borgonetti V, Cettolin G, Giachetti D, Magnano AR Miraldi E, Biagi M (2018) Phytotherapy in the management of diabetes: a review. Molecules (Basel, Switzerland) 23(1): e105. https://doi. org/10.3390/molecules23010105

Harding JL, Pavkov ME, Magliano DJ, Shaw JE, Gregg EW (2019) Global trends in diabetes complications: a review of current evidence. $\mathrm{Di}$ abetologia 62(1): 3-16. https://doi.org/10.1007/s00125-018-4711-2

International Diabetes Federation (2019) IDF Diabetes Atlas. $9^{\text {th }}$ edn., Brussels. http://www.diabetesatlas.org

Kooti W, Farokhipour M, Asadzadeh Z, Ashtary-Larky D, Asadi-Samani M (2016) The role of medicinal plants in the treatment of diabetes: a systematic review. Electronic physician 8(1): 1832-1842. https://doi. org/10.19082/1832

Li K, Sinclair AJ, Zhao F, Li D (2018) Uncommon fatty acids and cardiometabolic health. Nutrients 10(10): e1559. https://doi. org/10.3390/nu10101559

Marchyshyn S, Polonets O, Savych A, Nakonechna S (2020) Determination of carbohydrates of Chrysanthemum morifolium L. leaves and flowers by GC-MS. Pharmakeftiki Journal 32(4): 202-212.

Oh YS, Jun HS (2014) Role of bioactive food components in diabetes prevention: effects on beta-cell function and preservation. Nutrition and Metabolic Insights 7: 51-59. https://doi.org/10.4137/NMI.S13589

Rogero MM, Calder PC (2018) Obesity, inflammation, toll-like receptor 4 and fatty acids. Nutrients. 10(4): e432. https://doi.org/10.3390/ nu10040432

Savych A, Marchyshyn S, Basaraba R (2020a) Determination of fatty acid composition content in the herbal antidiabetic collections. Pharmacia 67(3): 153-159. https://doi.org/10.3897/pharmacia.67.e51812 chain carboxylic acids in all plant raw materials were unsaturated fatty acids, their content was $55.3 \%$ in Urtica dioica L. leaf, $64.7 \%$ in Rosa majalis L. fruits, $60.5 \%$ in Vaccinium myrtillus L. leaf, 64.3\% in Mentha piperita L. herb and 51.7\% in Taraxacum officinale $\mathrm{L}$. roots. This indicates the feasibility of including each component in the antidiabetic mixture in order to form anticholesterolemic, anti-inflammatory, immunomodulatory and neuroprotective activity, due to the high content of omega-3, omega- 6 and omega- 9 fatty acids.

Savych A, Marchyshyn S, Basaraba R (2020b) Screening study of hypoglycemic activity of the herbal mixtures (Message 1). ScienceRise: Pharmaceutical Science 4(26): 40-46. https://doi.org/10.15587/25194852.2020.210734

Savych AO, Marchyshyn SM, Basaraba RY (2020c) Determination of hypoglycemic activity of the herbal mixtures in screening study. Pharmacology and Drug Toxicology 14(5): 344-351. https://doi. org/10.33250/14.05.344

Savych A, Marchyshyn S, Basaraba R, Lukanyuk M (2020d) Antihyperglycemic, hypolipidemic and antioxidant properties of the herbal mixtures in dexamethasone-induced insulin resistant rats. PharmacologyOnLine 2: 73-82.

Savych A, Marchyshyn S, Doroshenko O (2020e) Screening of hypoglycemic activity of herbal mixtures (Message 2). Ukrainian biopharmaceutical journal 3(64): 22-29. https://doi.org/10.24959/ubphj.20.281

Savych AO, Marchyshyn SM, Milian II (2020f) Screening study of hypoglycemic activity of herbal mixtures (Presentation 3). Clinical Pharmacy 24(4): 38-46. https://doi.org/10.24959/cphj.20.1537

Savych A, Marchyshyn S, Basaraba R, Kryskiw L (2021a) Determination of carboxylic acids content in the herbal mixtures by HPLC. ScienceRise: Pharmaceutical Science: 2(30): 33-39. https://doi. org/10.15587/2519-4852.2021.229132

Savych A, Marchyshyn S, Harnyk M, Kudria V, Ocheretniuk A (2021b) Determination of amino acids content in two samples of the plant mixtures by GC-MS. Pharmacia 68(1): 283-289. https://doi. org/10.3897/pharmacia.68.e63453

Savych AO, Marchyshyn S, Kozyr H, Yarema N (2021c) Determination of inulin in the herbal mixtures by GC-MS method. Pharmacia 68(1): 181-187. https://doi.org/10.3897/pharmacia.68.e55051

Savych A, Marchyshyn S, Milian I (2021d) Determination of carbohydrates in the herbal antidiabetic mixtures by GC-MC. Acta Pharmaceutica 71(3): 429-443. https://doi.org/10.2478/acph-2021-0026

Savych A, Marchyshyn S, Nakonechna S (2021e) Influence of some herbal mixtures on insulin resistance and glucose tolerance in rats. PharmacologyOnLine 1: 356-364.

Sears B, Perry M (2015) The role of fatty acids in insulin resistance. Lipids in Health and Disease 14: e121. https://doi.org/10.1186/s12944-015-0123-1

Skyler JS, Bakris GL, Bonifacio E, Darsow T, Eckel RH, Groop L, Groop PH, Handelsman Y, Inse RA, Mathieu C, McElvaine AT, Palmer JP, Pugliese A, Schatz DA, Sosenko JM, Wilding JP, Ratner RE (2017) Differentiation of diabetes by pathophysiology, natural history, and prognosis. Diabetes 66(2): 241-255. https://doi.org/10.2337/db16-0806

WHO (2003) WHO guidelines on good agricultural and mixture practices (GACP) for medicinal plants. World Health Organization, Geneva, 72 pp. https://apps.who.int/iris/handle/10665/42783 